\title{
Pioneering Asian franchise brands: Pho24 in Vietnam
}

\author{
Lorelle Frazer \\ Professor in Marketing \\ Director, Asia-Pacific Centre for Franchising Excellence \\ Griffith Business School \\ Griffith University \\ Australia \\ Email: L.Frazer@griffith.edu.au
}

\author{
Bill Merrilees \\ Professor in Marketing \\ Asia-Pacific Centre for Franchising Excellence \\ Griffith Business School \\ Griffith University \\ Australia \\ Email: Bill.Merrilees@griffith.edu.au
}

Acknowledgement: The authors are grateful of the cooperation of Dr Ly Qui Trung, Founder and Franchisor of Pho24, for allowing access to his organisation for this case study. 


\title{
Pioneering Asian franchise brands: Pho24 in Vietnam
}

\begin{abstract}
Pho24 is Vietnam's largest and most rapidly growing franchise system. In this research a case study approach is used to study the franchising strategy employed by the organisation to achieve rapid growth in Vietnam and internationally. Key people in the organisation were interviewed, including the founder/franchisor, franchisees and company employees. Data were collected over a 12 month period from the organisation's operations in three countries: Vietnam, Australia and Singapore. The findings indicate that cultural and legal contexts heavily influence the franchisor's philosophy. Traditional explanations of franchising, such as resource constraints theory and agency theory, only partially explain the motivations for franchising. An alternative hybrid model of franchising, an Asian partnership model of franchise brand management, is adopted to improve control and collaboration between the franchisor and franchisees.
\end{abstract}

Keywords: franchise, Vietnam, case study, born global, entrepreneur 


\section{Introduction}

There is an emerging literature on entrepreneurial brands (Doyle, 2003; Merrilees, 2007; Rode and Vallaster, 2005). However, few of these studies are in the Asian context and in particular almost nothing is known about home-grown Asian franchising brands. In part this is because there are limited examples of exemplar home-grown Asian franchising brands and in part because of a lack of access to those brands in this category. Fortunately, the current study has access to Vietnam's most successful home grown franchise brand, Pho24 and is able to document the basis of the brand's birth and development, emphasising the design of the brand vision and essence and the supporting brand management system (the franchising model).

Very little is known about Asian franchising brands. It seems that the penetration of franchising is more limited in Asia, though the reasons for this are unclear. Additionally, little is known about the extent to which Asian franchise brands have primarily used Western approaches to franchise brand management or whether these systems have been adapted to suit the Asian context. The initial expectation was that some adaption of the franchise brand management system occurs in an Asian context, with the purpose of the paper to more precisely analyse the nature of this adaption.

The objective of the current paper is to tackle these two questions, namely to document the birth and development of Vietnam's leading home-grown franchise brand, Pho24 and to analyse the extent of franchise brand management system adaption in an Asian context. That is, the paper investigates Vietnam's largest franchise brand system, Pho24, the first major domestic franchising system developed 
and grown in Vietnam. Vietnam is touted as a potential next wave Asian tiger, adding to the intrigue to find out the state of the art franchising currently in that country. Franchise branding is a particularly useful context for better understanding of how brand concepts are developed in a creative sense and then managed (through a franchise brand system).

Essentially a case method approach is used around the Pho24 organization. Special attention was given to the brand founder and entrepreneur, Dr Ly Qui Trung.

\section{Traditional franchising brand models}

Most franchising models focus on the financial, management control and marketing motivation for franchising, to which we will turn shortly. Very few of the models discuss the initial design of the franchising brand. The study can therefore contribute to the fledgling literature of entrepreneurial branding. Currently that literature emphasises the strong role of the founder in shaping the brand (Abimbola, 2001; Doyle, 2003; Krake, 2005; Merrilees, 2007; Rode and Vallaster, 2005) which the current study endorses. The same entrepreneurial branding literature emphasises the importance of corporate over product branding, again a sentiment echoed in the current study.

The traditional franchising model, that is, one that is common in developed nations such as the United States or Australia, typically views franchising as an efficient method of distribution of goods and services due to its reliance on the human capital contributed by franchisee owner managers (Birkeland 2002). Moreover, it is the ability of the franchisee and franchisor to specialise and contribute in different ways 
to the business relationship that provides a comparative advantage over alternative organisational structures (Blair and Lafontaine 2005). The early literature viewed franchising as a temporary strategy to be used by small start-up companies in order to achieve rapid growth despite the reluctance of capital markets to back their investments (Oxenfeldt and Kelly 1969). This capital acquisition explanation argued that organisations were forced to resort to franchising because it allowed them to expand quickly without having to source scarce external financial resources or to relinquish control as in a joint venture or stock market operation (Caves and Murphy 1976). Thus, over time it was expected that franchisors would repurchase or take over the (best) franchised units in the system and eventually become fully company owned (Oxenfeldt and Kelly 1969).

However, research into this phenomenon has produced mixed results in the United States (for example, Hunt 1973, Brickley and Dark 1987, Lafontaine 1992). Moreover, it has been found that where ownership redirection occurs it is "more strategy driven than opportunistic" (Dant, Kauffman and Robicheaux 1998, p. i). Indeed, Blair and Lafontaine (2005) comment that "most franchise chains are hybrids: partially vertically integrated and partially franchised" (p. 107). In contrast, while some large fast food chains (such as McDonald's) strategically ensure a mix of franchised and company owned units, most franchise systems in Australia are almost fully franchised (Frazer, Weaven and Wright 2008). Hence, different franchising models are employed around the world and there is no 'one size fits all' approach. An alternative explanation of franchising, first put forward by Rubin (1978), focuses on creating a contractual relationship which provides efficiencies and incentives for both parties to achieve maximum benefits. It is based on the premise that, in order to 
expand, some outlets will be located at a geographical distance from the franchisor, thus making it difficult to fully observe and monitor their operations. Employee managers may be motivated to act in their own self interest rather than the firm's. For instance, in the absence of any additional rewards and where their actions are difficult to observe, employee managers will not be specifically motivated to work harder than necessary or to maximise efficiency of operations. Hence, franchising provides a workable solution to the problem encountered in agency relationships by focusing on the substance, rather than the economics, of the relationship (Brickley and Dark 1987). Franchising becomes an efficient distribution channel due to "increased owner commitment and reduced control and monitoring costs" (Hoy and Stanworth 2003, p. 60).

For the past several decades scholars around the world have sought evidence to support these alternative, but not exclusive, theories of franchising. Findings have been somewhat mixed, with most commentators now concurring that a combination of both resource constraints and agency theories serves to explain why franchising occurs. For example, Australian research has found support that franchisors initially use franchising as a means of expansion when the franchisor is financially constrained, whilst at the same time choosing franchising in order to minimise franchisor risk (Frazer and Stokes 1997). Research in the United States confirms the role of the franchisor in controlling the use and value of the brand and that of franchisees to control ongoing operations (Birkeland 2002). These different approaches are also evident at the operational level. The traditional concept of a franchisee is the so-called 'mom and pop' model whereby the franchisee operates a single unit (Grunhagen and Mittelstaedt 2002). Research in Australia reveals that this 
model is pervasive with the majority of franchises operating as husband/wife single unit partnerships (Frazer, Weaven and Wright 2008). However, in the more mature franchising sector in the United States, most franchises are owned by multiple unit operators: "Single-unit franchisees are the exception, not the rule." (Kaufmann 1996, p.5). It is clear that different variations of franchising exist around the world and so now we turn to the model adopted by Pho24 in Vietnam.

\section{Asian models of franchise brand management}

The literature on franchising in Asia is less developed, reflecting the relative infancy of the franchising sectors in Asian nations. Recent work exploring Asian franchising includes that of Wang, Zhu and Terry (2008) who have written about franchising in China, Terry (2008) on Vietnam, and Paswan (2008) who has explored the growth of franchising in India. Yet, this developing body of work is mostly descriptive, filling a gap in our knowledge about Asian franchising practice, but hardly venturing towards comparisons of western and Asian franchising or analysing the different brand models. Moreover, Dant (2008) urges researchers to apply existing theories crossculturally and to "look beyond the North American contexts for data and original theoretical development" (p. 1). Hence, this current research contributes significantly to our understanding of franchising in Asia by exploring in depth a home-grown Vietnamese system that has expanded both domestically and internationally.

\section{Background for Pho24 - the founder of the brand and the company}

The Pho24 brand is a major part of the Nam An Group, which overall comprises more than a dozen different brands, including Maxim's and Terrace café. The first Pho24 
branded store opened in June 2003 and by 2011 there were 52 stores in Vietnam and 21 stores overseas in Korea, Cambodia, Philippines, Hong Kong, Macau, Australia and Indonesia. One third of the stores in Vietnam are franchised compared with 100 percent franchising in all overseas markets (mostly using master franchising arrangements). Sales for the entire franchise system were US\$12 million in 2010. Plans were under way to open stores in Japan, China and the United States in 20112012. Table 1 details the history and growth of the company's international operations. The franchise comes close to be described as a born global firm (Rennie 1993, Deshpande 1983), consistent with the initial mission of the company to be "a worldwide brand". It is the largest franchise system in Vietnam. Studies vary but often require a firm to go global in the first three years and to build up a critical mass of overseas sales relative to domestic sales. Perhaps Pho24 falls just short of this standard, given that it entered international markets after four years and is still not quite at a critical level of overseas sales. However, we will argue in the conclusions that perhaps a different (somewhat easier) standard is needed to judge Asian-based franchise "born globals".

Table 1

Pho24 International Expansion

\begin{tabular}{|l|r|r|r|}
\hline Country & Number of stores & Year of entry & $\begin{array}{r}\text { Proportion } \\
\text { franchising }\end{array}$ \\
\hline Vietnam & 52 & 2003 & $33 \%$ \\
Korea & 2 & 2007 & $100 \%$ \\
Indonesia & 11 & 2007 & $100 \%$ \\
Cambodia & 1 & 2008 & $100 \%$ \\
Australia & 1 & 2008 & $100 \%$ \\
Singapore* & 1 & 2008 & $100 \%$ \\
Philippines & 2 & 2008 & $100 \%$ \\
Hong Kong & 3 & 2010 & $100 \%$ \\
Macau & 1 & 2011 & $100 \%$ \\
\hline Total stores & 73 & & \\
\hline
\end{tabular}

* Singapore store closed in 2009 due to poor performance 
The founder of the brand, Dr Ly Qui Trung, is a pioneer in every respect, not simply developing a new brand concept, but doing so in a national context where there are few home-grown brands. The brand concept is based on the Vietnamese pho (phôû) noodle which is national dish in Vietnam. However, rather than a simple street food presentation as is common, the dish is packaged in a modern day style. Understandably, it is a major challenge to take a cheap street food which is a national dish, with decades of tradition and habits and offer a higher-priced Western-presented equivalent. The inspiration for format, like many other franchises, is the McDonald's brand, with its modern, clean and consistent image projection. However the Pho24 brand launch is more dramatic than the initial McDonald's launch because it required consumers to switch from a flexible, chaotic presentation to a structured and orderly food and restaurant presentation. Note that the 24 refers to the 24 ingredients in the noodle dish, analogous to KFC's eleven secret ingredients.

\section{Methodology and data collection method}

A qualitative approach was used in this research because of the complexity of the study (involving franchise operations across several countries) and the length of time needed to gather the data (Gummesson 2006). Flexibility was essential as the study adopted a recursive approach (Veal 2005), collecting and analysing data concurrently as the research evolved. A single case study of Pho24 was undertaken in order to conduct an in-depth investigation of the organisation, its formation, development and expansion internationally. This organisation was chosen because it provided an opportunity to study a unique form of brand franchising (Stake 2000). A distinct advantage of using a single case study is the ability to study the organisation holistically (Zikmund and Babin 2007). Our objective was to gain a comprehensive 
understanding of the franchising brand strategy of Pho24 (Punch 1998). We were particularly fortunate in having access to, and the full cooperation of, the founder of the organisation who held specialised knowledge due to his high profile as a leading Vietnamese businessman, entrepreneur and scholar (Ritchie and Lewis 2003). While the research referred to prior theory as a starting point, the case study was used for the purpose of inductive theory building (Perry 1998). Explanatory case studies attempt to provide an explanation for how and why particular events occur (Yin 2003) and, as such, are very powerful forms of research.

Data were collected over a 12 month period in Australia, Vietnam and Singapore and comprised a series of interviews, store visits, observations and review of company documents. Interviews were used to gather empirical data about the organisation by asking people to talk about their experiences and interactions (Holstein and Gubrium 2004). The founder of the Pho24 brand, Dr Ly Qui Trung, was interviewed personally on three occasions by the researchers, twice when he visited Australia and once at his corporate office in Ho Chi Minh City (HCMC) in Vietnam. Key employees in the organisation, including the Human Resources Manager and Business Development Manager, were interviewed in Vietnam. Six franchisees were also personally interviewed, each by one of the researchers. Two were single unit franchisees in Vietnam. A third held multiple units in Vietnam and was also the master franchisee for Korea. The fourth person was a franchisee operating in Australia and the fifth and sixth people were partners in a franchise in Singapore. Finally, a Senior Trade Commissioner attached to the Australian Embassy in Hanoi was also personally interviewed, providing an 'outsider' perspective. This person shared his extensive knowledge of the local business environment and legal framework of Vietnam. All 
but three of the participants communicated fluently in English; in these cases (one corporate office employee and two franchisees) an interpreter was present to translate from Vietnamese. In most cases the interviews were tape recorded and transcribed and were analysed manually by each of the researchers. Where it was not feasible to record the interview, detailed notes were maintained. Mindful of differences in language and culture, we used Whyte's hierarchy of interviewer responses to encourage reflection and to probe participants' responses (Whyte 1982).

In addition to these interviews, several Pho24 outlets were visited in order to inspect the operations and observe interactions with customers. These were the corporate head office pilot operation (HCMC); a corporate store, corporate kiosk and a franchised outlet in HCMC; and franchisee stores in Singapore and Sydney, Australia. During the store visits we were able to note the interactions between employees and customers and observe and compare the physical condition of the outlets. Participant observation and fieldwork are hallmarks of rigorous qualitative research (Delamont 2004), enabling the researchers to test and revisit initial insights. For instance, we noticed a marked difference in the standard of the store showcased at corporate headquarters with that of the franchised outlets causing us to seek further information from the franchisor about quality control.

Initially, an assortment of documents about the organisation was scrutinised. These included internal company documents, such as organisational charts, as well as publicly available documents, including the Mission and Vision statement and promotional materials. Scrutiny of this documentation assisted the researchers in understanding the culture of the organisation. The use of a combination of data 
sources - interviews, observations and document analysis - enabled us to validate and cross check our findings as the research progressed (Patton 2002). Indeed, using a combination of data types contributed to the validity of the research (Silverman 2006).

The very subjective nature of qualitative research demands checks and balances to be put in place to ensure rigour and to avoid the intrinsic bias that accompanies a single approach. Hence, several forms of triangulation were used in this research. By having two researchers involved in the project, investigator triangulation was achieved, enabling alternative perspectives to be explored (Patton 2002). Triangulation of data sources was used to improve the depth and quality of data collection and analyses (Silverman 2006). This technique involved, for example, comparing interviews with observations and contrasting the perspectives of different people. Finally, triangulation of theory occurred as the research incorporated two major (rival) theoretical perspectives - resource constraints theory and agency theory - in order to interpret the findings (Neuman 2006).

\section{The Pho24 franchising brand model}

Most of the Pho24 brand franchisees are established successful businessmen. There are no 'mom and pop' examples in existence as this would be inconsistent with Vietnamese culture. The franchisees are owner investors, rather than owner operators. The franchise may be one of many business interests which they oversee and therefore only a portion of the franchisee's time is devoted to the franchise. A store manager takes care of the day-to-day operations under the direction of the franchisee 
but with a minimum of contact. For example, the Korean master franchisee who also held five outlets in Vietnam, visits only one or two stores a week to take a look around and speak to the manager.

.... I manage the managers. There are managers and vice managers. I own many managers.

This level of involvement is very different to Australian multiple unit franchisees who tend to dedicate their time fully to the management of the unit holdings (Weaven and Frazer 2003).

The franchising relationship also differs. In western cultures the franchisor-franchisee relationship is personal and involved and has been compared to marriage or a parentchild relationship (Nathan 2008). Similarly, franchisees normally associate either formally or informally in order to network and share ideas. However, the behaviour of franchisor and franchisees in Pho24 is less personal. The franchisees do not normally interact, unless they are attending a seminar or a formal meeting. The Korean master franchisee delegates the task of relationship building to his staff members.

When the (other franchisees) have a seminar I talk to them but, otherwise, personally I don't contact them. (There was) a meeting last year for franchisee owners and I didn't go there because I was busy. My staff went there and they met other franchisees who were Vietnamese.

The founder keeps in regular contact with the franchisees but with bounded parameters. For instance, although the franchisees mostly interact with corporate office management, Dr Trung likes to make an effort to contact them personally:

I ask my secretary to remind me to call them sometimes personally, even though I have the account manager or business development manager to look after all the franchisees, but sometimes I do like to call them and say hello and they feel important. 
However, when asked whether he knew anything about the families of the franchisees he indicated that it would be detrimental to the business relationship to develop personal relationships with franchisees:

In Vietnam it is quite sensitive. If you go too much into the relationship then you cannot manage. You can't be good friends or they don't listen to you. Work relationship but not friends; if it becomes like friends then I cannot work.

When asked about the nature of franchisor-franchisee interaction in Pho24, all the franchisees we interviewed indicated the relationship was quite formal. However, franchisees felt that the franchisor was responsive as illustrated in this comment:

(They) detect and give an order to fix something ... and they understand local franchisee conditions ... even though we have to follow their system, they listen.

Further, a Vietnamese franchisee alluded to the tension faces by franchisees, who are motivated to control costs, and the franchisor, who wishes to maintain quality standards:

... the relationship between the franchisee and franchisor is very important ... both sides need to see mutual benefits ... in the interest of the brand.

This emphasis on the business relationship permeates the model used in Pho24. Like many other franchise systems, there is a mix of company owned and franchised outlets. The franchisor indicated that company owned stores were more profitable than franchisee operations because franchisees tended to control costs:

The negative thing about franchised stores is the quality of the food. I am concerned most of the complaints from the customers are with the franchised stores.

This statement is somewhat contrary to the Western literature which predicts that franchisees will outperform managers due to greater personal incentives to perform (Bradach 1998), but the situation in Pho24 is different because the franchisees are not 
hands-on operators. The attempt to reduce costs results in lower quality products and service, ultimately leading to diminishing revenues and profits. Given the superior performance of the company stores one would expect that the company would maximise its ownership of outlets unless it faced resource constraints. In the case of the Pho24 brand, the constraint is on human, rather than financial, resources as noted by Dr Trung:

I make more profit and earn more money if I open a company store, but of course they have to balance with the capacity of management. If all 60 stores belonged to the company then I don't think I could maintain the system.

The main hindrance to brand system expansion is due to managerial capacity to service the operations. Franchising provides a partial solution for the organisation by devolving responsibility for management to franchisee investors. Capital could be sourced from franchisees but a venture capitalist has invested in the organisation, thus alleviating the need to raise capital for expansion via franchising. Hence, resource constraints theory is applicable to this case only to the extent of the shortage of human capital.

The normal (Western) franchising brand model relies on franchisees as owner operators to overcome agency problems, such as shirking or free riding on the brand, and to align franchisor-franchisee goals (Brickley and Dark 1987). However, in the Pho24 (Asian) brand model the franchisees are owner investors and are not involved in either hands-on operation or close supervision of the business. Such a model is at risk of suffering a loss of brand consistency and reduction of quality of product and service offerings. To minimise the risk, the franchisor invests in each franchise unit and becomes a part owner. Being in partnership with each franchisee allows the franchisor to maintain control: 
I adjusted (the system) quite a lot to match the Vietnam context. For example, when I started to franchise I didn't want to just sell the franchise but (I wanted) to sell the franchise plus my shares as a shareholder. The concept was at least 30 percent of investment from Pho24 to any franchisee store.....that way I feel safer, I feel I have better control of the franchisee.

This level of brand control is beneficial because of the unique nature of the franchisees. As they are successful businessmen with diverse business interests, they are unlike novice first-time business owners who will accept advice and guidance from the franchisor. By becoming a partner in their businesses, the franchisor is able to exert more control and direction over the business activities, thus reducing the potential for conflict in the relationship. One such example involved a franchisee who attempted to cut costs by reducing the amount of meat served to customers. When confronted with customer complaints through the corporate office the franchisee conceded that the franchisor and franchisee relationship was built around mutual success.

We follow the system now ... for the franchisee, their profit is first ... but franchisors have to make profits. So we always have to find a solution to make a profit.

Legal, as well as, cultural issues may influence this choice of collaborative model as businesses in Vietnam cannot rely on the regulatory system for protection (Terry 2008). Dr Trung commented "I have no choice but to joint venture with them under a franchise contract". The Human Resources Manager provided a similar explanation:

We need control and so that is why we have the voice of the franchisee and the voice of the partner. That is why (Trung) wants to control the company.

This brand model is unique to the franchise operations in Vietnam. In other countries where the company has expanded, such as Singapore, Korea, Indonesia and the Philippines, master franchising arrangements are used, with no capital investment by the franchisor. The exception is the first outlet opened in Australia, which is a joint venture arrangement, but future development in Australia will be via master 
franchising. The fact that the partnership model is essentially used only in Vietnam lends support to the notion that the franchisor, who is a pioneer of brand franchising in that country, has had to adapt the franchising brand model to make it work under unique circumstances.

To a large extent the franchise brand management model developed in Vietnam seems unique. However in broad terms it can be generalised to an extent into what we term an "Asian partnership model of franchise brand management". The characteristics of this model include the partial or full separation of the franchisee role and the franchise brand operation management role. As explained, this reflects the lack of mum and pop franchisee owners, with potentially separate people owning the franchisee (through investment) and others running the operations. This is particularly true of the Vietnam operations, but also true of Pho24 operations in Singapore as well. Separate research by the authors, reveals that this pattern of separate ownership and management is common in India as well and possibly other Asian countries. Typically, Asian people interested in managing franchises lack the capital and equally people with capital to invest in a franchisee lack interest or time to manage the franchise. This is the people dilemma that underpins the necessity for the Asian partnership model of franchise brand management.

Separation makes control of the franchise brand more difficult compared to the Western model where the person who invests in the franchise also helps manage it. The additional brand control issue may explain why franchise brands are less prevalent in Asia. Extra vigilance is required. For example, initially the separate 
operators were inclined to cut costs by reducing air conditioning usage, but this risked damage to the brand.

A special Pho24 solution to the separation problem is the co-investment in individual franchisees by the franchisor. Such co-investment reinforces the "partnership" model both in terms of financial investment and facilitating or legitimising the founder taking a closer role in the operations of each franchisee. In other words, if the special Asian problem of separation occurs with the risk of inconsistent brand delivery, coinvestment facilitates and enables more direct brand control by the franchisor.

To his credit, the founder, Dr Ly Qui Trung, has made a major contribution in developing the "Asian partnership model of franchise brand management" in practice and making it work. The contribution of the researchers is to identify the term and nature of such a franchise brand management model and to conceptualise the components and properties of such a system.

\section{Conclusions}

This research has examined a single case study in depth to study how an emerging brand has faced the complex cultural and legal environment in which it operates in order to flourish. Access to Pho24, its founder, franchisees and employees has enabled us to analyse the company's unique franchising model, both in terms of the entrepreneurial development of a franchise brand and especially the development of a franchise brand management system suited to the Asian context. In terms of the first objective, the study provides one of the few academic papers on entrepreneurial development of a brand in franchising. Previous descriptions of this phenomenon 
have mainly been popular books of particular franchise systems, such as McDonald's (Love 1988) or Jim's Mowing in Australia (Penman 1992). Pho24 is a valuable addition to understanding entrepreneurial branding, especially in Asia.

The dominant theories of franchising - resource constraints and agency theories have been applied to the case and we conclude that they provide a partial explanation for the franchising model adopted. Like most organisations, Pho24 requires human and financial capital in order to expand. Company operated outlets are more profitable than franchised outlets because of the tendency of franchisees to cut costs, but the resultant loss of quality reduces income and profits.

However, the organisation does not have the managerial capacity to continue to expand via company ownership and therefore requires franchisees to share the responsibility. Rather than use franchising as a means of raising scarce capital, the organisation has obtained finance from a venture capitalist. Hence, resource constraints theory only partially contributes to the understanding of why Pho24 operates as a hybrid franchising model. The rival agency theory of franchising is similarly unable to offer a full explanation for Pho24's strategy.

Although the franchise agreement provides incentives for both parties to achieve mutual goals, the franchisees who are recruited into Pho24 are business investors rather than operators and hence, the franchise brand is of greater importance to them than the franchising relationship. Therefore, in order to adapt to the cultural and legal environment the franchisor has modified the franchising model in order to achieve greater control within the system. Rather than exerting authority and highlighting the 
power differential between franchisor and franchisee, the Vietnamese culture requires a persuasive and more patient approach that stresses equity in the relationship. This is truly more of a 'partnership' approach than demonstrated in the Western style of franchising and we refer to this as the "Asian partnership model of franchise brand management".

Because Pho24 is a pioneering home-grown franchise in Vietnam, we are not able to fully test the robustness of the partnership model on other franchise systems in that country. However, there are similarities amongst various Asian cultures (India in particular) and it is possible that this model of franchise brand management will be one that is suitable for adoption in other Asian nations. Notwithstanding, the proposed "Asian partnership model of franchise brand management" has only been applied to one Asian country, Vietnam. While it has promise as a generalised Asian model of franchise brand management it requires further testing in other Asian countries. Further research in other Asian countries would also be interesting to see how brand concepts are developed in those countries, especially in the context of very Asian concepts, such as the phôû-based Pho24 brand.

The study also has implications for Asian-based franchise global branding. It was suggested in the background to Pho24 that perhaps it fell slightly short of the Western standard for a "born-global" company. However, conjecturally, a different (easier) standard is needed in the Asian franchise brand context. The co-investment strategy of Pho24 limits the resource-enhancement benefit of franchising and necessitates a slower growth of the brand domestically, thus providing fewer funds for international expansion. The same co-investment strategies apply to franchisees in the new 
international markets, again necessitating slower growth. In other words, the Asian partnership model of franchise brand management indicates a slower road to globalization for Asian-based franchise brands. 


\section{References}

Abimbola, T. (2001). Branding as a competitive strategy for demand management in SMEs. Journal of Research in Marketing \& Entrepreneurship, 3(2), 97-106.

Birkeland, P.M. (2002). Franchising Dreams: The Lure of Entrepreneurship in America. Chicago: The University of Chicago Press.

Blair, R.D., \& Lafontaine, F. (2005). The Economics of Franchising. New York: Cambridge University Press.

Bradach, J. (1998). Franchise Organizations. Boston, Massachusetts: Harvard Business School Press.

Brickley, J., \& Dark, F. (1987). The choice of organizational form: The case of Franchising. Journal of Financial Economics, 18(June), 401-420.

Caves, R., \& Murphy, W.F. (1976). Franchising: Firms, Markets and Intangible Assets. Southern Economic Journal, 42(4), 572-586.

Dant, R. (2008). A Futuristic Research Agenda for the Field of Franchising. Journal of Small Business Management, 46(1) January, 91-98.

Dant, R., P., Kaufmann, \& Robicheaux, R. (1998). Changes in the Mix of Companyowned and Franchised Outlets: Ownership Redirection Revisited. In F. Lafontaine (Ed.), Proceedings of the $12^{\text {th }}$ Conference of the Society of Franchising (pp. 1-16). Las Vegas.

Dant, R., Paswan, A., \& Kaufmann, P. (1996). What we know about ownership redirection in franchising: A meta-analysis. Journal of Retailing, 72(4), 429444.

Dant, R., Perrigot, R., \& Cliquet ,G. (2008). A Cross-Cultural Comparison of the Plural Forms in Franchise Networks: United States, France, and Brazil. Journal of Small Business Management, 46(2), 286-311.

Delamont, S. (2004). Ethnography and Participant Observation. In C. Seale, G. Gobo, J. Gubrium, J., \& D. Silverman (Eds.), Qualitative Research Practice (pp. 217229). London: Sage.

Deshpande, R. (1983). Paradigms lost: On theory and method in research in Marketing. Journal of Marketing, 47(Fall), 101-10.

Doyle, E. (2003). A study of entrepreneurial brand building in the manufacturing sector in the UK. Journal of Product \& Brand Management, 12(2), 79-93.

Frazer, L., \& Stokes, D. (1997). Franchising operational units in Australia.

Franchising Research: An International Journal, 2(1), 32-42.

Frazer, L., Weaven, S., \& Wright, O.(2008). Franchising Australia. Brisbane: Griffith University.

Grunhagen, M., \& Mittelstaedt, R.A. (2002). Is bigger better? The anticipation of scale efficiencies and decision participation as motivations for aspiring multiunit franchisees. International Journal of Entrepreneurial Behaviour \& Research, 8(3), 188-200.

Gummesson, E. (2006). Qualitative research in management: addressing complexity, context and persona. Management Decision, 44(2), 167-179.

Holstein, J.A., \& Gubrium, J.F. (2004). The active interview. In D. Silverman (Ed.), Qualitative Research: Theory, Method and Practice (pp. 140-161). London: Sage.

Hoy, F., \& Stanworth, J. (2003). Franchising: An International Perspective. New York: Routledge. 
Hunt, S.D. (1973). The trend towards company-operated units in franchise chains. In A. Oxenfeldt (Ed.), Franchising: Recent Trends (pp. 110-119). Journal of Retailing.

Kaufmann, P. (1996). The state of research in franchising. Franchising Research: An International Journal, 1(1), 4-7.

Krake, F. (2005). Successful brand management in SMEs: a new theory and practical hints. Journal of Product \& Brand Management, 14(4), 228-238.

Lafontaine, F. (1992). Agency Theory and Franchising: Some Empirical Results. Rand Journal of Economics, 23(2), Summer, 263-283.

Love, J. (1988). McDonald's - Behind the Arches. London: Bantam.

Merrilees, B. (2007). A theory of brand-led SME new venture development. Qualitative Market Research, 10(4), 403-415.

Nathan, G. (2008). Profitable Partnerships. $7^{\text {th }}$ Edition. Brisbane: Franchise Relationships Institute.

Neuman, W. (2006). Social Research Methods: Qualitative and Quantitative Approaches. $6^{\text {th }}$ Edition. USA: Pearson.

Oxenfeldt, A.R., \& Kelly, A.O. (1969). Will successful franchise systems ultimately become wholly owned chains? Journal of Retailing, 44, 69-87.

Paswan, A. (2008). Franchising in India: An Evolutionary Perspective. In G. Cliquet (Ed.), Proceedings of International Society of Franchising $22^{\text {nd }}$ Annual Conference. France: St Malo.

Patton, M.Q. (2002). Qualitative Research and Evaluation Methods. $3^{\text {rd }}$ Edition. London: Sage.

Penman, J. (1992). The Cutting Edge: Jim's Mowing: A Franchise Story. Australia: White Kite Productions.

Perry, C. (1998). Processes of a case study methodology for post graduate research in marketing. European Journal of Marketing, 32(9/10), 785-802.

Punch, K. (1998). Introduction to Social Research: Quantitative and Qualitative Approaches. London: Sage.

Rennie, M. (1993). Born global. The Mckinsey Journal, 4, 45-52.

Ritchie, J., \& Lewis, J. (2003). Qualitative Research Practice: A Guide for Social Science Students and Researchers. London: Sage.

Rode, V., \& Vallaster, C. (2005). Corporate branding for start-ups: the crucial role of entrepreneurs. Corporate Reputation Review, 8(2), 121-135.

Rubin, P. (1978). The Theory of the Firm and the Structure of the Franchise Contract. Journal of Law and Economics, 21(April), 223-233.

Silverman, D. (2006). Doing Qualitative Research. $2^{\text {nd }}$ Edition. London: Sage.

Stake, R. (2000). Case Studies. In N. Denzin, \& Y. Lincoln (Eds.), Handbook of Qualitative Research, $2^{\text {nd }}$ Edition (pp. 435-454). London: Sage.

Terry, A. (2008). Asia's Next Franchising Frontier: Good Morning Vietnam! In G. Cliquet (Ed.), Proceedings of International Society of Franchising $22^{\text {nd }}$ Annual Conference. France: St Malo.

Veal, A. (2005). Business Research Methods: A Managerial Approach. $2^{\text {nd }}$ Edition. Australia: Pearson Education.

Wang, Z.J., Zhu, M., \& Terry, A. (2008). The Development of Franchising in China. Journal of Marketing Channels, 15,(2/3), 167-184.

Watson, A., \& Stanworth, J. (2006). Franchising and intellectual capital: A franchisee's perspective. The International Entrepreneurship and Management Journal, 2(3), September, 337-349. 
Weaven, S., \& Frazer, L. (2003). Predicting Multiple Unit Franchising: A Franchisor and Franchisee Perspective. Journal of Marketing Channels, 10(3/4), 53-82.

Whyte, W.F. (1982). Interviewing in field research. In R.G. Burgess (Ed.), Field Research: A Sourcebook and Field Manual (pp. 111-122). London: Allen \& Unwin.

Yin, R. (2003). Case Study Research: Design and Methods. Thousand Oaks, California: Sage.

Zikmund, W., \& Babin, B. (2007). Exploring Marketing Research. 9th Edition. USA: Thomson. 